\title{
Erratum to: Turning the page
}

\author{
Juleen R. Zierath ${ }^{1,2}$
}

Published online: 15 October 2015

(C) Springer-Verlag Berlin Heidelberg 2015

\section{Erratum to: Diabetologia}

\section{DOI 10.1007/s00125-015-3764-8}

Unfortunately Professor Zierath's middle initial was omitted in the version of this editorial that originally appeared online. This error has now been corrected.

The online version of the original article can be found under doi:10.1007/ s00125-015-3764-8.

$\triangle$ Juleen R. Zierath

Juleen.Zierath@ki.se

1 Department of Molecular Medicine and Surgery, Karolinska Institutet, Von Eulers Väg 4a, 4 Tr., 17177 Stockholm, Sweden

2 Department of Physiology and Pharmacology, Karolinska Institutet, Stockholm, Sweden 